\title{
KLAUSULA EKSONERASI SEBAGAI PERJANJIAN BAKU DALAM PERJANJIAN ASURANSI
}

\author{
Wiwin Wintarsih Windiantina \\ Fakultas Hukum Universitas Pamulang \\ E-Mail: dosen00484@unpam.ac.id
}

\begin{abstract}
Abstrak
Perjanjian baku mengharuskan semua ketentuan yang ada dalam suatu perjanjian menghilangkan hak konsumen untuk melakukan negosiasi yang di dalam perjanjian asuransi lajim disebut dengan klausula eksonerasi di mana tanggungjawab dibatasi berdasarkan kepentingan sepihak. Asuransi menerima peralihan risiko dari adanya evenement, Perjanjian antara tertanggung dan penanggung di tuangkan dalam suatu akta tertulis yang disebut polis, dalam tatanan praktisnya perjanjian Asuransi agar dapat dinyatakan sah, maka harus berdasarkan kepada pasal 1320 KUHPerdata dan pasal 251 KUHD (Notification). Dalam tulisan ini akan diuraikan mengenai bagaimana akibat hukum dengan adanya klausula eksonerasi sebagai perjanjian baku dalam polis Asuransi. Penelitian ini menggunakan metode penelitian hukum normatif dengan pendekatan perundang-undangan yang mengkaji Undang-undang No. 8 Tahun 1999 Tentang Perlindungan Konsumen dan pasal 1320 KUHPdt serta aturan-aturan lain yang relevan. Hasil penelitian ini menemukan bahwa dengan adanya penuangan klausula eksonerasi dalam perjanjian baku dapat menimbulkan kerugian pada pihak tertanggung dikarenakan adanya penafsiran pemahaman isi kesepakatan pada hubungan kontraktual para pihak. Dengan demikian, perjanjian dapat dibatalkan dan batal demi hukum karena tidak memenuhi syarat kesepakatan.
\end{abstract}

Kata kunci: klausula eksonerasi; perjanjian baku; asuransi.

\begin{abstract}
The standard agreement requires that all provisions contained in an agreement eliminate the consumer's right to negotiate, which in the normal insurance agreement is called an exoneration clause in which responsibilities are limited based on unilateral interests. Insurance accepts a risk shift from an event. The agreement between the insured and the guarantor is stated in a written deed called the policy, in the practical arrangement of the Insurance agreement to be declared valid, it must be based on article 1320 of the Civil Code and article 251 of the KUHD (Notification).In this paper, we will describe the legal consequences of the existence of an exoneration clause as a standard agreement in the Insurance policy. This study uses a normative legal research method with a legislative approach that examines Law No. 8 of 1999 concerning Consumer Protection and article 1320 of the Indonesian Criminal Code and other relevant rules. The results of this study found that
\end{abstract}


the pouring of an exoneration clause in a standard agreement could cause losses to the insured party due to an interpretation of the understanding of the contents of the agreement on the contractual relationship of the parties. Thus, the agreement can be canceled and null and void because it does not meet the terms of the agreement.

Keywords: exoneration clause; standard agreement; insurance.

\section{Pendahuluan}

Masyarakat harus menyadari urgensinya suatu perlindungan terhadap berbagai ancaman atau risiko dikemudian hari, hal tersebut salah satu yang memicu tingginya penggunaan asuransi. Kesempatan itu merupakan peluang besar bagi perusahaan asuransi sekaligus sebagai tantangan yang menghasilkan keuntungan dalam usaha pelayanan jasa asuransi, dimana pasar asuransi tidak berbatas waktu dan wilayah, berbagai produk diciptakan untuk disampaikan kepada konsumen dalam upaya mencapai sasaran penjualan ${ }^{1}$.

Akan tetapi sangat dimungkinkan tidak sedikit masyarakat yang belum memahami tentang manfaat Asuransi atau bahkan sama sekali tidak mengerti tentang klausul eksonerasi sebagai perjanjian baku (standar contract). Hal ini akibat dari kurangnya transparansi dan sosialisasi terutama dari pihak Asuransi sebagai pihak penanggung dan sebagai pihak yang membuat perjanjian baku dengan klausula eksonerasi.

Eksonerasi atau exoneration (Bahasa Inggris) diartikan oleh I. P. M Ranuhandoko B.A. dalam bukunya, "Terminologi Hukum Inggris Indonesia", yaitu, pemberian kebebasan terhadap seseorang dalam upaya lepas dari tuntutan dan tanggungjawab. ${ }^{2}$ Secara sederhana, klausula eksonerasi ini diartikan sebagai klausula pengecualian kewajiban dan atau pertanggungjawaban dalam perjanjian dari pihak yang menentukan perjanjian pada kondisi ini pihak Asuransi sebagai pihak penanggung. Karena adanya ketidak seimbangan antara pihak Penanggung dan Tertanggung, secara substansial pihak yang menentukan telah menuangkan syarat dalam perjanjian dalam bentuk pengalihan tanggungjawab atau yang lajim kita sebut sebgai klausula eksonerasi. Tanggungjawab dibatasi dengan pembebasan yang pada hakikatnya merupakan kewajiban atau tanggungjawabnya dalam bentuk hubungan kontraktual pada perjanjian yang bersifat baku.

Klausula eksonerasi dituangkan dalam perjanjian baku dan jika ditelaah berdasarkan syarat sahnya perjanjian sebagaimana yang diatur dalam Pasal

${ }^{1}$ Deny Guntara, Asuransi dan Ketentuan-ketentuan Hukum Yang Mengaturnya, Jurnal Justisi Ilmu Hukum, Vol 1, No. 1, 2016

${ }^{2}$ Klausula Eksonerasi, www.hukumonline.com, diakses 11 Mei 2020. 
1320 KUHPerdata berimplikasi pada keabsahan atau pembatalan suatu perjanjian karena hilangnya makna kesepakatan sebagai salah satu syarat sahnya suatu perjanjian sehingga perjanjian tersebut dapat dikatakan cacat kehendak yang digunakan oleh salah satu pihak untuk menentukan isi suatu perjanjian. Lebih jauh lagi jika ditelaah berdasarkan Undang-undang Nomor 8 tahun 1999 tentang perlindungan konsumen akan berakibat batal demi hukum karena adanya klausula eksonerasi. ${ }^{3}$

Asas kebebasan berkontrak memungkinkan adanya klausula eksonerasi sebagaimana kandungan makna Pasal 1338 KUHPerdata. Ikatan perjanjian para pihak merupakan substansi pokok dalam pasal tersebut yang melahirkan hak dan kewajiban. Namun demikian, hubungan kontraktual dapat dilakukan oleh siapapun dengan isi perjanjian yang sesuai dengan kepentingan para pihak. Keleluasaan dalam membuat perjanjian dibatasi dengan norma kesusilaan dan ketertiban umum, keleluasaan tersebut bahkan dapat mengesampingkan peraturan yang tertuang dalam KUHPerdata atau yang lajim kita sebut dengan sistem terbuka (openbaar system).

Salah satu contoh klausula eksonerasi yang sering ditemukan dalam polis asuransi antara lain klausula yang pada intinya menyatakan bahwa tertanggung tunduk terhadap peraturan yang berupa aturan baru, tambahan, lanjutan dan/atau pengubahan lanjutan yang dibuat sepihak oleh penanggung tanpa kesepakatan tertanggung selama masa pertanggungan asuransi. Hal ini sangat merugikan pihak tetanggung karena tidak adanya keseimbangan hak dengan pihak Penanggung. Sehingga konsekuensi bagi Polis asuransi yang mencantumkan klausula eksonerasi maka polis asuransi tersebut dinyatakan batal demi hukum sesuai dengan ketentuan Pasal 18 ayat (3) Undang-undang Nomor 8 Tahun 1999 Tentang Perlindungan Konsumen, tanpa mengurangi hak tertanggung untuk mengajukan upaya hukum dalam hal menderita kerugian atas dicantumkannya klausula eksonerasi sebagaimana telah dijelaskan diatas.

\section{Permasalahan}

Tulisan ini akan memaparkan secara khusus mengenai Pertama, bagaimana keabsahan penerapan klausula eksonerasi sebagai perjanjian baku ditinjau dari syarat sah perjanjian asuransi ? Kedua, bagaimana dampak Penerapan klausula eksonerasi sebagai perjanjian baku ditinjau dari Undangundang Nomor 8 Tahun 1999 Tentang Perlindungan Konsumen ?

${ }^{3}$ Zakiyah, Klausula Eksonerasi dalam Perspektif Perlindungan Konsumen, Jurnal Al'Adl, Vol IX No. 3, Desember 2017 


\section{Metode Penelitian}

Pada tulisan ini menggunakan jenis penelitian yang bersifat normatif dimana norma-norma hukum sebagai acuan utama baik yang terdapat dalam peraturan perundang-undangan maupun dalam teori-teori hukum para ahli hukum. Telaah juga dilakukan dengan mengkomparasikan perjanjian yang bersifat baku pada perjanjian asuransi yang di dalamnya terdapat klausula eksonerasi. Data yang digunakan merupakan data dalam bentuk kajian kepustakaan sebagaimana lajimnya penelitian normatif dalam bentuk peraturan perundang-undangan, buku, jurnal dan sumber literatur lainnya sebagai referensi yang dapat dipertanggungjawabkan. Data sekunder maupun primer dielaborasi dengan analisis kualitatif dilakukan secara sistematis dalam upaya menjawab permasalahan dalam penelitian ini. harapan dalam tulisan ini dapat memberikan pengetahuan secara teoritis pada perjanjian asuransi dengan klausula eksonerasi dalam tatanan keabsahan perjanjian serta implikasi dari hubungan kontraktual perjanjian asuransi itu sendiri.

\section{Pembahasan}

\section{Penerapan Klausula Eksonerasi Sebagai Perjanjian Baku (Standar Contract) dalam Perjanjian Asuransi}

"Usaha Perasuransian adalah segala usaha menyangkut jasa pertanggungan atau pengelolaan risiko, pertanggungan ulang risiko, pemasaran dan distribusi produk asuransi atau produk asuransi syariah, konsultasi dan keperantaraan asuransi, asuransi syariah, reasuransi, atau reasuransi syariah, atau penilaian kerugian asuransi atau asuransi syariah" (Pasal 1 ayat 4, Undang-undang No. 40 Tahun 2014 tentang Perasuransian).

Hubungan kontraktual dalam sebuah perjanjian asuransi dalam bentuk polis asuransi disebut dengan insurer yang melakukan kesepakatan dengan insurance taker yang merupakan pemegang polis yang substansinya adalah kesepakatan pembayaran premi asuransi dimana pihak insured party menyediakan dana atas kerugian yang diderita insurable interest tentunya setelah klaim diajukan dengan syarat dan ketentuan yang telah disepakati bersama, baik pada suatu peristiwa yang tidak dapat diprediksi di masa yang akan datang. Para pihak harus memegang teguh itikad baik dalam perjanjian tersebut untuk menghindari terjadinya insurance fraud yang dapat merugikan kedua belah pihak baik langsung maupun tidak langsung.

Prinsip-prinsip yang harus dipegang teguh oleh para pelaku usaha dalam upaya melindungi konsumen khususnya pada sektor jasa keuangan adalah pemenuhan tranparansi pada produk yang ditawarkan kepada para konsumen dalam bentuk informasi yang benar baik kejelasan produk, secara lengkap dan 
dengan menggunakan bahasa yang sederhana dan dapat dipahami serta pemenuhan rasa keadilan terhadap konsumen. ${ }^{4}$

Asuransi sebagai pelaku usaha jasa keuangan, memiliki kewajiban memberikan perlindungan terhadap konsumennya (tertanggung) sebagai pengguna produk dan/atau layanannya. Hal ini dikarenakan Asuransi menghimpun dana masyarakat dengan sejumlah uang yang dibayarkan oleh pihak tertanggung berupa premi sebagai kompensasi atas pengalihan risiko yang telah diperjanjikan, maka antara pihak Penanggung dan Tertanggung harus memiliki hak dan kewajiban yang seimbang. Asuransi adalah perjanjian antara dua pihak, yaitu perusahaan asuransi dan pemegang polis, yang menjadi dasar bagi penerimaan premi oleh perusahaan asuransi (Pasal 1 ayat 1, Undang-undang Nomor 40 Tahun 2014 Tentang Perasuransian).

Sebagai suatu Perjanjian, penyusunan atau pembuatan polis asuransi harus memperhatikan ketentuan Pasal 1320 Kitab Undang Undang Hukum Perdata dan pasal 251 KUHD. KUHPerdata menyebutkan kesepakatan merupakan salah satu syarat sahnya perjanjian dan KUHD mengharuskan adanya notification tentang objek dan subjek Asuransi yang dituangkan di dalam klausul Polis. Di dalam dasar hukum tersebut terdapat asas-asas yang harus ditaati oleh pihak-pihak yang berkepentingan, yakni pihak penanggung (perusahaan asuransi) dan pihak tertanggung (pemegang polis). Dengan demikian, perjanjian asuransi dapat dinyatakan sah dan polis asuransi dapat dinyatakan mengikat para pihak dan menimbulkan hubungan keperdataan antara penanggung dan tertanggung apabila keduanya telah sama-sama sepakat untuk tunduk pada perjanjian asuransi tersebut.

Sebagai salah satu bentuk pencapaian kesepakatan, penyusunan suatu perjanjian pada umumnya melibatkan para pihak untuk menyetujui dan tidak menyetujui hal-hal tertentu yang selanjutnya akan dicantumkan dalam Perjanjian. Namun, hal tersebut berbeda pada saat penyusunan polis asuransi yang memiliki intensitas tinggi dengan substansi yang diatur dalam perjanjian relatif sejenis. Perusahaan Asuransi seringkali telah mempersiapkan suatu perjanjian baku (standardized contract) dengan klausula eksonerasi untuk alasan kepraktisan dan efisiensi sehingga tertanggung hanya diberikan kesempatan untuk memutuskan menerima atau menolak polis asuransi yang telah dibuat secara sepihak oleh Perusahaan Asuransi. Apabila tertanggung memutuskan untuk menerima, maka tertanggung dinyatakan telah sepakat dan tunduk atas semua ketentuan dalam polis asuransi tersebut.

\footnotetext{
${ }^{4}$ Ketut Sendra, Kecurangan dan Perlindungan Konsumen Asuransi, Jurnal Vokasi Indonesia, Vol. 5 No. 1 Jan-Jun 2017
} 
Moch Isnaini menjelaskan substansi adanya perjanjian baku digunakan oleh pihak yang mempunyai kewenangan dan posisi tawar yang lebih tinggi untuk memanfaatkan kesempatan terhadap orang yang mempunyai kebutuhan untuk melakukan perjanjian tersebut, sehingga hilangnya makna berimbang atau proporsionalitas dalam perjanjian. Implikasi dari perjanjian tersebut mengakibatkan adanya kerugian karena tertutupnya daya tawar salah satu pihak bahkan sampai hilangnya syarat-syarat perjanjian substansial, akan tetapi disisi lain salah satu pihak harus menerima kondisi tersebut karena adanya kebutuhan yang mendesak. ${ }^{5}$

Pihak asuransi (penanggung) mempersiapkan perjanjian baku sepihak pada hubungan kontraktual. Pembatasan syarat perjanjian yang dapat menghilangkan hak salah satu pihak dengan mengutamakan pembatasan kewajiban pihak penanggung. eksonerasi klausules atau exemption clause merupakan sebuah kelajiman dalan suatu perjanjian asuransi, namun tertanggung tidak dapat menolak persyaratan tersebut sehingga sangat memungkinkan terjadinya kerugian terhadap tertanggung.

Rijken mendepinisikan Klausula eksonerasi adalah klausul yang tercantum dalam sebuah hubungan kontraktual dengan upaya menghindarkan diri dalam pemenuhan suatu kewajiban dalam bentuk penggantian kerugian baik seluruh atau sebagian karena pengingkaran terhadap perjanjian. ${ }^{6}$ Substansi dari beberapa pendapat ahli pada tulisan ini dapat dikatakan esonerasi merupakan klausul pembebasan tanggungjawab pada hubungan kontraktual yang tidak seharusnya dengan pelepasan tanggungjawab yang telah ditentukan dalam perjanjian tersebut. Kemestian pembebanan tanggungjawab dialihkan untuk melindungi kepentingan salah satu pihak dengan pengalihan kewajiban.

Sebagai upaya adanya kesetaraan hak dan kewajiban bagi para pihak dalam perjanjian asuransi dan untuk menghindari adanya pihak yang dirugikan, maka sutu perjanjian harus memiliki unsur kesepakatan. Suatu perjanjian haruslah tidak menyalahgunakan keadaan karena hal ini merupakan salah satu bentuk cacat kehendak. BW (Burgerlijk Wetboek tidak mengenal adanya penyalahgunaan keadaan atau daya tawar dalam suatu perjanjian, namun pada faktanya penyalahgunaan keadaan sebagai bentuk kecatatan kehendak dalam suatu perjanjian berdasarkan putuskan Mahkamah Agung Republik Indonesia Nomor 1904K/Sip/1982 tanggal 28 Januari 1984 dan putusan Mahkamah Agung Republik Indonesia nomor 3431K/Pdt/1985 tanggal 4

${ }^{5}$ Moch. Isnaeni, Perkembangan Hukum Perdata di Indonesia, Laksbang Grafika, Yogyakarta, 2013, hlm.18-19.

${ }^{6}$ Ahmadi Miru, Hukum Kontrak, Perancangan Kontrak, PT. Raja Grafindo Perkasa, Jakarta, 2007, hlm. 40. 
Maret $1987^{7}$ suatu perjanjian terlahir dalam bentuk keabsahan, syarat sahnya suatu perjanjian yang substansinya terdapat dalam Pasal 1320 Burgerlijk Wetboek (BW) dimana kesepakatan sebagai unsur utama dalam pengikatan diri, para pihak harus dianggap cakap melakukan perjanjian, adanya objek dalam perjanjian sebagai suatu hal yang diperjanjikan, kebolehan objek perjanjian atau kehalalan objek perjanjian. Subyektifitas pada syarat kesepakatan dalam suatu perjanjian dapat berimplikasi kebatalan, karena adanya unsur yang dapat mengakibatkan kerugian terhadap orang lain baik secara langsung maupun tidak langsung. ${ }^{8}$

Pasal 251 KUHD menggarisbawahi tertanggung diharuskan memberikan informasi terhadap semua kondisi yang diketahuinya pada objek pertanggungungan, sebagai upaya memitigasi besar dan kecilnya risiko yang dapat diberikan oleh tertanggung, keberadaan objek benda merupakan milik tertanggung serta dikuasasi oleh tertanggun. ${ }^{9}$ Sebagai upaya untuk menghindari kerugian akibat klausula eksonerasi, maka pada saat melakukan suatu perjanjian selain berpedoman kepada pasal 1320 KUHPerdata sebagai syarat subjektif, pasal 251 KUHD harus disertakan dan dijadikan pedoman dalam perjanjian tersebut. Hal ini bertujuan untuk menciptakan adanya kesetaraan hak dan kewajiban para pihak.

Pencantuman klausula eksonerasi yang memberatkan pihak Tertanggung, dapat dikatakan merupakan pembatasan terhadap asas kebebasan berkontrak (pasal 1338 KUHPerdata), karena kebebasan ini hanya dikuasai oleh salah satu pihak yang posisinya relatif lebih kuat, sehingga klausula eksonerasi dalam perjanjian baku hanya ditentukan oleh pihak Penanggung tanpa melibatkan pihak tertanggung, hal ini memungkinkan pihak Penanggung dengan leluasa menyalahgunakan keadaan ini. Kerugian yang mungkin timbul dari klausula eksonerasi akan dialami oleh pihak tertanggung. Permasalahan yang selalu dialami oleh pihak tertanggung adalah sulitnya memperoleh pembayaran ganti kerugian ketika evenement terjadi. ${ }^{10}$

7J.M.van Dunne dan Gr van der Brught, "Hukum Perjanjian", Bahan Kursus Hukum Perikatan Bagian 1a, Dewan Kerjasama Ilmu Hukum Belanda dengan Indonesia, Yogyakarta, 1987, hlm. 30.

${ }^{8}$ Kartini Mulyadi, Perikatan yang Lahir dari Perjanjian, PT. RajaGrafindo Persada, Jakarta, 2004, hlm. 172.

9Prinsip Umum Asuransi”, www.kompasiana.com, diakses paga tanggal 13 Mei 2020

${ }^{10}$ Sunarmi, Pemegang Polis Asuransi dan Kedudukan Hukumnya, Jurnal Ilmu Hukum, Vol. 3 No. 1 
Ekonerasi merupakan salah satu bentuk perjanjian baku(standar contract) dalam bentuk penyalahgunaan kondisi oleh salah satu pihak yang mempunyai kekuasaan untuk menentukan syarat perjanjian dengan menghilangkan makna kesepakatan secara subtansial, dengan demikian perjanjian yang dibuat yang seperti itu dapat dikatakan tidak memenuhi salah satu syarat perjanjian yaitu adanya kesepakatan para pihak.

Kondisi seperti itu meskipun klausula eksonerasi secara teoritis dapat dikatakan batal, karena terpenuhinya unsur hilangnya kesepakatan dengan penyalahgunaan kondisi masih tetap berlaku selama belum adanya keputusan pengadilan yang membatalkan keputusan tersebut. Pasal 1266 KUHPerdata menegaskan "Dalam hal yang demikian perjanjian tidak batal demi hukum, tetapi pembatalan harus dimintakan kepada hakim".

\section{Perlindungan Hukum Bagi Konsumen (Tertanggung) Terhadap Klausula Eksonerasi Sebagai Perjanjian Baku dalam Polis Asuransi.}

Konsensualitas dalam suatu perjanjian asuransi terlihat dalam bentuk hubungan kontraktual yang dituangkan dalam bentuk akta polis asuransi. Polis salah satu instrumen alat bukti dalam suatu perjanjian pertanggungan. Keberadaan pertanggungan tersebut ditentukan dengan berbagai syarat sebagai pembebanan pengalihan kerugian atau risiko kepada pihak penanggung terhadap suatu peristiwa di masa yang akan datang. Pengalihan kerugian tersebut lajim disebut dengan klaim asuransi sebagai bagian prestasi yang harus tunaikan oleh penanggung terhadap tertanggung karena adanya pembayaran premi asuransi. ${ }^{11}$

Pengalihan kerugian yang derita oleh konsumen dalam bentuk hubungan kontraktual kepada pihak asuransi dapat berbentuk perjanjian baku yang di dalamnya terkandung klausula eksonerasi. Draf perjanjian telah dibuat dalam bentuk perjanjian baku oleh pihak asuransi untuk memenuhi kebutuhan konsumen dengan syarat dan ketentuan yang telah dibuat berdasarkan kepentingan perusahaan asuransi.

E.H. Hondius menjelaskan depinisi secara terminologi perjanjian baku suatu konsep perjanjian yang terdiri dari syarat dan ketentuan yang dituangkan dalam suatu hubungan kontraktual dalam bentuk polis yang jumlah serta isinya tanpa melalui proses pembicaraan. ${ }^{12}$ Pasal 1 angka 10 Undang-Undang Nomor 8 Tahun 1999 memberikan definisi klausula baku adalah "setiap aturan atau ketentuan dan syarat-syarat yang telah

${ }^{11}$ Budi Badruzaman, Perlindungan Hukum Tertanggung dalam Pembayaran Klaim Asuransi Jiwa, Jurnal Ekonomi dan Keuangan Syari'ah Vol. 3 No. 1 Januari 2019

${ }^{12}$ Kelik Wardiono, Perjanjian Baku Klausul Eksonerasi dan Konsumen, Penerbit Ombak, Surakarta, 2014, hlm. 10 
dipersiapkan dan ditetapkan terlebih dahulu secara sepihak oleh pelaku usaha yang dituangkan dalam suatu dokumen dan/atau perjanjian yang mengikat dan wajib dipatuhi oleh konsumen".

Klausula eksonerasi memberikan beban tersendiri terhadap konsumen yang dapat menyalahi keabsahan suatu perjanjian, sehingga dikatakan kebebasan berkontrak tidak dapat tercapai oleh karena penguasaan oleh salah satu pihak yang mempunyai daya tawar lebih kuat. Klausula baku pada perjanjian baku hanya ditentukan oleh pihak pelaku usaha tanpa melibatkan pihak konsumen (tertanggung), hal ini memungkinkan pelaku usaha dengan leluasa menyalahgunakan keadaan. Salah satu contoh klausula eksonerasi yang sering ditemukan dalam polis asuransi antara lain klausula yang pada intinya menyatakan bahwa tertanggung tunduk terhadap peraturan yang berupa aturan baru, tambahan, lanjutan dan/atau pengubahan lanjutan yang dibuat sepihak oleh penanggung tanpa kesepakatan tertanggung selama masa pertanggungan asuransi.

Peran pemerintah sangat dibutuhkan dalam upaya melindungi masyarakat sebagai konsumen dengan sungguh-sunguh. Dalam upaya memberikan perlindungan yang lebih baik, maka pemerintah sudah seharusnya dapat melakukan perlindungan hukum secara preventif. Perlu disadari upaya perlindungan konsumen yang dilakukan oleh pemerintah melalui Undangundang Nomor 8 Tahun 1999 Tentang Perlindungan Konsumen memang sangatlah terbatas, akan tetapi upaya yang dilakukan pemerintah tersebut merupakan salah satu upaya untuk membatasi kerugian konsumen akibat penggunaan klausula eksonerasi dalam perjanjian.

Pencantuman klausula eksonerasi sebagai perjanjian baku dalam polis asuransi yang dibuat secara sepihak oleh Perusahaan Asuransi pada dasarnya tidak bertentangan dengan aturan-aturan hukum mengenai perjanjian asuransi di Indonesia. Hal demikian menjadi dilarang ketika perusahaan asuransi menerapkan klausula baku yang bertentangan dengan ketentuan-ketentuan Pasal 18 Ayat 1 Undang-undang Nomor 8 Tahun 1999 Tentang Perlindungan Konsumen.

Hak dan Kewajiban para pihak berdasarkan tujuan dari lahirnya Undang-undang Nomor 8 Tahun 1999 Tentang Perlindungan Konsumen di atas, maka perlu diatur apa yang menjadi hak dan kewajibannya. Pada Pasal 4 Undang-undang Nomor 8 Tahun 1999 Tentang Perlindungan Konsumen, mengatur tentang hak Konsumen yaitu hak atas informasi yang benar, jelas, dan jujur mengenai kondisi dan jaminan barang dan/atau jasa; hak untuk didengar pendapat dan keluhannya atas barang dan/atau jasa yang digunakan; hak untuk mendapatkan advokasi, perlindungan, dan upaya penyelesaian sengketa perlindungan konsumen secara patut; hak untuk mendapat 
pembinaan dan pendidikan konsumen; hak untuk diperlakukan atau dilayani secara benar dan jujur serta tidak diskriminatif; hak-hak yang diatur dalam ketentuan peraturan perundang-undangan lainnya. Pada Pasal 5 Undangundang Nomor 8 Tahun 1999 Tentang Perlindungan Konsumen, mengatur tentang kewajibannya yaitu: (a) membaca atau mengikuti petunjuk informasi dan prosedur pemakaian atau pemanfaatan barang dan/atau jasa, demi keamanan dan keselamatan; (b) beritikad baik dalam melakukan transaksi pembelian barang dan/atau jasa; (c) mengikuti perlindungan konsumen secara patut.

Berdasarkan ketentuan Pasal 5 (a) di atas, bahwa dalam jasa Asuransi, Konsumen Asuransipun atau disebut Tertanggung, berkewajiban untuk membaca dan memberikan keterangan yang jujur dan akurat pada aplikasi asuransi sebelum aplikasi tersebut ditandatangani. Demikian pula wajib membaca isi polis dengan tujuan untuk membuktikan apakah polis yang diterimanya sesuai dengan yang ditawarkan oleh Pelaku Usaha dan atau yang diminta melalui lembar aplikasi asuransi yang ditandatangani.

Dengan terbitnya beberapa peraturan yang mengatur tentang Perlindungan Konsumen pada jasa keuangan, permasalahannya yaitu bagaimana Pelaku Usaha dapat segera menyesuaikan dan bagaimana juga Konsumen dan masyarakat luas memiliki pengetahuan, keyakinan, dan keterampilan serta kemampuan untuk mengelola keuangan dengan lebih baik.

Melihat ketentuan tersebut di atas, maka keabsahan dari perjanjian baku yang mencantumkan klausula pengalihan tanggung jawab pelaku usaha (yang dikenal dengan istilah klausula eksonerasi), berakibat klausula tersebut dinyatakan batal demi hukum. Sehingga konsekuensi bagi Polis asuransi yang mencantumkan klausula eksonerasi dimaksud diatas maka polis asuransi tersebut dinyatakan batal demi hukum sesuai dengan ketentuan Pasal 18 ayat (3) Undang-undang Nomor 8 tahun 1999 Tentang Perlindungan Konsumen.

Konsumen tanpa mengurangi haknya sebagai tertanggung, dengan kesadarannya sendiri dapat mengajukan upaya hukum dengan mengajukan gugatan ke pengadilan, dalam hal menderita kerugian atas dicantumkannya klausula eksonerasi sebagaimana yang telah dijelaskan diatas. Hal demikian sebagai upaya hukum terakhir untuk mendapatkan haknya sebagai Tertanggung guna memeperoleh perlindungan hukum secara penuh melalui pembatalan perjanjian yang dibatalkan oleh hakim melalui putusan Pengadilan.

Asuransi sebagai sebuah perjanjian bukan sekedar berisi kesepakatan (konsensualisme) tertanggung dan penanggung, tetapi juga harus memenuhi syarat agar perjanjian tersebut sah. Perjanjian asuransi sebagaimana umumnya perjanjian, juga harus memenuhi unsur-unsur pasal 1320 
KUHPerdata tentang persyaratan dalam perjanjian, diantaranya ada kesepakatan kedua belah pihak, kecakapan untuk melakukan perbuatan hukum, adanya objek dan adanya kausa yang halal. ${ }^{13}$ Kontrak dalam asuransi yang dimana diadakan antara perusahaan asuransi dengan konsumen atau nasabah membuat suatu perjanjian dalam bentuk surat perjanjian yang diberi nama polis, di dalam polis ini dijabarkan secara terperinci berkenaan dengan syarat, hak, serta kewajiban kedua belah pihak dalam perjanjian tersebut, termasuk mencantumkan jumlah pertanggungan, jangka waktu, serta resiko yang akan ditanggung perusahaan asuransi sebagai penanggung. ${ }^{14}$

Adakalanya dalam negosiasi kontrak menempatkan salah satu pihak dalam posisi yang tidak seimbang, dengan menerapkan klausula eksonerasi dalam perjanjian baku sehingga kontrak tersebut menguntungkan salah satu pihak saja. Sehubungan dengan perlindungan terhadap konsumen, yang perlu mendapat perhatian utama dalam perjanjian baku adalah mengenai klausula eksonerasi (exoneratie klausule exemption clausule). Yaitu klausula yang berisi pembebasan atau pembatasan pertanggungjawaban dari pihak pelaku usaha yang lazimnya terdapat dalam jenis perjanjian tersebut. ${ }^{15}$

Klausula eksonerasi yang biasanya dimuat dalam perjanjian sebagai klausula tambahan atas unsur esensial dari suatu perjanjian, pada umumnya ditemukan dalam perjanjian baku. Klausula tersebut merupakan klausula yang sangat merugikan konsumen yang umumnya memiliki posisi lemah jika dibandingkan dengan produsen, karena beban yang seharusnya dipikul oleh produsen, dengan adanya klausula tersebut menjadi beban konsumen. ${ }^{16}$ Walaupun secara yuridis sering dinyatakan antara pelaku usaha dan konsumen berkedudukan sama, tetapi faktanya konsumen adalah pihak yang biasanya harus selalu menuruti ketentuan yang telah ditetapkan oleh pelaku usaha. Pelaku usaha dapat dengan sepihak menghilangkan kewajiban yang seharusnya dipikulnya. Adanya ketidakseimbangan penggunaan perjanjian baku dalam perjanjian asuransi memberi dampak pada perlindungan hak yang sepihak pada penanggung dari pada Tertanggung, sehingga lebih banyak risiko atau kerugian yang harus dipikul oleh Tertanggung. Hal ini tidak dikehendaki dan tidak dibenarkan, karena hukum bertujuan untuk memberi keadilan dan

${ }^{13}$ Kuat Ismanto, Principle of utmost good faith dalam perjanjian asuransi, Studi Asas Hukum Perjanjian Syari'ah, Jurnal Episteme, Vol. 7 No. 2 Desember 2012

${ }^{14}$ Abi Robian, Fungsi Perlindungan Konsumen Atas Penggunaan Klausula Baku di Indonesia Mengacu pada Undang-undang Nomor 8 Tahun 19999 Tentang Perlindungan Konsumen, Jurnal Pendidikan Kewarganegaraan, Vol. 4, No.1, Maret 2017

${ }^{15}$ Bure Teguh Satria, Eksistensi dan Akibat Hukum Perlindungan Konsumen, Sinar Grafika, Jakarta, 2011, hlm. 58.

${ }^{16}$ Ahmadi Miru, Larangan Penggunaan Klausula Baku Tertentu dalam Perjanjian Antara Konsumen dan Pelaku Usaha, Jurnal Hukum, Vol. 8 No. 17, Juni 2001. 
mengayomi semua pihak. Perjanjian baku yang dibuat harus memenuhi persayaratan yang dimaksud dalam Pasal 1320 KUHPerdata, sehingga status perjanjian dengan klausul baku tetap sah. Dalam hal klausula eksonerasi yang dibuat dalam perjanjian baku, jika tidak memenuhi syarat subjektif maka dapat dibatalkan melalui gugatan pembatalan kontrak perjanjian ke pengadilan dan jika tidak memenuhi persyaratan objektif, maka kontrak batal demi hukum.

Undang-undang Perlindungan Konsumen tidak melarang pelaku usaha untuk membuat klausula baku atas setiap dokumen dan perjanjian transaksi usaha perdagangan barang atau jasa, selama dan sepanjang klausula baku tersebut tidak mencantumkan ketentuan sebagaimana dilarang dalam Pasal 18 ayat (1), serta tidak "berbentuk klausula eksonerasi” sebagaimana dilarang dalam pasal 18 ayat (2) Undang-Undang Perlindungan Konsumen tersebut" ${ }^{17}$ Format dan isi klausula eksonerasi dalam perjanjian baku biasanya telah dirancang dan dibuat oleh pihak yang memiliki kedudukan dan posisi lebih kuat. Sehingga perjanjian yang seharusnya dibuat/dirancang oleh para pihak yang terlibat dalam perjanjian tidak ditemukan lagi. Dengan demikian maka klausula eksonerasi dalam perjanjian baku sangat merugikan konsumen atau tertanggung yang umumnya memiliki posisi lemah jika dibandingkan dengan produsen atau penanggung, karena beban yang seharusnya dipikul oleh produsen atau penanggung, dengan adanya klausul tersebut menjadi beban konsumen atau tetanggung.

Konsep itu sudah tidak sesuai lagi, sebab sudah tidak selaras dengan perkembangan hukum. Dalam hal ini, klausula baku erat kaitannya dengan Undang-undang Nomor 8 Tahun 1999 Tentang Perlindungan Konsumen, yang telah secara tegas dan detil mengatur hak dan kewajiban konsumen, hak dan kewajiban pelaku usaha, serta hal-hal yang dilarang dilakukan oleh pelaku usaha. Khusus mengenai perjanjian baku ini, Undang-undang Nomor 8 Tahun 1999 Tentang Perlindungan Konsumen melarang dengan tegas pencantuman klausula eksonerasi pada setiap dokumen dan/atau perjanjian yang tujuannya merugikan konsumen. Dan pelanggaran ketentuan ini mengakibatkan klausula eksonerasi dalam perjanjian baku tersebut batal demi hukum, namun walaupun berakibat batal demi hukum, tetap diperlukan adanya kesadaran dan keberanian konsumen atau tertanggung untuk mengajukan gugatan pembatalan klausula eksonerasi dalam perjanjian baku tersebut sebagai upaya hukum terakhir ke pengadilan.

\footnotetext{
${ }^{17}$ Celina Kristiyanti, Hukum Perlindungan Konsumen, Sinar Grafika, Jakarta, 2011,
} hlm. 58. 


\section{Penutup}

\section{Simpulan}

Penuangan klausula eksonerasi dalam perjanjian baku dapat menimbulkan kerugian pada pihak tertanggung dikarenakan adanya penafsiran pemahaman isi kesepakatan pada hubungan kontraktual para pihak. Dengan demikian, perjanjian dapat dibatalkan dan batal demi hukum karena tidak memenuhi syarat kesepakatan. Penuangan klasukan eksenorasi pada perjanjian asuransi merupakan hal yang sudah lajim dilakukan pada hubungan kontraktual para pihak, namun jika dirasakan merugikan salah satu pihak maka konsumen dapat melakukan pengajuan gugatan secara litigasi.

\section{Saran}

Berdasarkan pembahasan di atas maka saran penulis, calon konsumen harus cermat dan teliti dalam membaca isi kontrak yang terdapat dalam dalam perjanjian baku sebagai upaya pencegahan kerugian yang lebih besar dikemudian hari oleh konsumen. karena klausula eksonerasi dalam perjanjian baku banyak terjadi dalam kehidupan masyarakat sehari-hari. Bagi para pelaku usaha asuransi hendaknya tidak selalu berfikir keuntungan namun mengesampingkan aspek keabsahan suatu perjanjian, menutup pintu negosiasi salah satu pihak dengan klausula eksonerasi merupakan perbuatan yang dapat dikualifisir mengesampingkan aspek syarat sah perjanjian yaitu kesepakatan para pihak. Kebijaksanaan pihak asuransi suatu hal yang diharapkan sehingga masyarakat dapat tercerahkan pada perjanjian yang telah disepakati bersama.

\section{Daftar Pustaka}

\section{Buku}

Ahmadi Miru, Hukum Kontrak, Perancangan Kontrak, PT. Raja Grafindo Perkasa, Jakarta, 2007.

Bure Teguh Satria, Eksistensi dan Akibat Hukum Perlindungan Konsumen, Sinar Grafika, Jakarta, 2011.

Celina Kristiyanti, Hukum Perlindungan Konsumen, Sinar Grafika, Jakarta 2011.

Kartini Mulyadi, Perikatan yang Lahir dari Perjanjian, PT. RajaGrafindo Persada, Jakarta, 2004.

Kelik Wardiono, Perjanjian Baku Klausul Eksonerasi dan Konsumen, Penerbit Ombak, Surakarta, 2014.

Moch. Isnaeni, Perkembangan Hukum Perdata di Indonesia, Laksbang Grafika, Yogyakarta, 2013. 
Jurnal

Abi Robian, "Fungsi Perlindungan Konsumen Atas Penggunaan Klausula Baku di Indonesia Mengacu pada Undang-undang Nomor 8 Tahun 19999 Tentang Perlindungan Konsumen”, Jurnal Pendidikan Kewarganegaraan, Vol. 4, No.1, Maret 2017.

Ahmadi Miru, "Larangan Penggunaan Klausula Baku Tertentu dalam Perjanjian Antara Konsumen dan Pelaku Usaha”, Jurnal Hukum, Vol. 8 No. 17, Juni 2001.

Budi Badruzaman, "Perlindungan Hukum Tertanggung dalam Pembayaran Klaim Asuransi Jiwa”, Jurnal Ekonomi dan Keuangan Syari'ah, Vol. 3 No. 1 Januari 2019.

Deny Guntara, "Asuransi dan Ketentuan-ketentuan Hukum Yang Mengaturnya”, Jurnal Justisi Ilmu Hukum, Vol 1, No. 1, 2016

Ketut Sendra, "Kecurangan dan Perlindungan Konsumen Asuransi", Jurnal Vokasi Indonesia, Vol. 5 No. 1 Jan-Jun 2017.

Kuat Ismanto, "Principle of utmost good faith dalam perjanjian asuransi, Studi Asas Hukum Perjanjian Syari'ah”, Jurnal Episteme, Vol. 7 No. 2 Desember 2012.

Sunarmi, "Pemegang Polis Asuransi dan Kedudukan Hukumnya", Jurnal Ilmu Hukum, Vol. 3 No. 1.

Zakiyah, "Klausula Eksonerasi dalam Perspektif Perlindungan Konsumen", Jurnal Al'Adl, Vol IX No. 3, Desember 2017.

\section{Makalah}

J.M.van Dunne dan Gr van der Brught, "Hukum Perjanjian”, "Bahan Kursus Hukum Perikatan Bagian 1a", Dewan Kerjasama Ilmu Hukum Belanda dengan Indonesia, Yogyakarta, 1987.

\section{Internet}

“Klausula Eksonerasi”, www.hukumonline.com, diakses 11 Mei 2020

“Prinsip Umum Asuransi”, www.kompasiana.com, diakses tanggal 13 Mei 2020

\section{Peraturan Perundang-Undangan}

Kitab Undang-undang Hukum Perdata

Kitab Undang-undang Hukum Dagang

Undang-Undang Nomor 40 Tahun 2014 Tentang Perasuransian

Undang-Undang Nomor 8 Tahun 1999 Tentang Perlindungan Konsumen 